\title{
Assessment of surface friction of self-ligating brackets under conditions of angulated traction
}

Roberta Buzzoni', Carlos N. Elias², Daniel J. Fernandes³, José Augusto M. Miguel ${ }^{4}$

Objective: The aim of this study was to assess resistance to sliding of stainless steel passive self-ligating brackets with $0^{\circ}$ and $2.5^{\circ}$ angulations and to compare them to active self-ligating brackets at zero angulation. The hypothesis to be tested was that passive self-ligating brackets produce lower frictional forces than active self-ligating brackets.

Methods: Twenty five $0.022 \times 0.028$-in slot maxillary canine brackets were divided into 5 groups of 5 brackets: Damon SL II (Ormco, CA, USA) self-ligating bracket and Gemini (3M/Unitek, CA, USA) conventional bracket with angulation of 0 and $2.5^{\circ}$ and a group of Speed 2 (American Orthodontics, WI, USA) active clip self-ligating system with zero angulation. Twenty five segments of stainless steel 0.020-in archwire (TP Orthodontics, IN, USA) were tested and each bracket/wire interface was evaluated at 4 successive points during sliding. Overall, 100 frictional values were analyzed by parametric analysis of variance and Bonferroni tests.

Results and Conclusion: Frictional tests were performed with an Emic DL 10000 testing machine (Emic, Brazil) with a load cell of one kilogram. Passive self-ligating brackets produced lower frictional forces than active selfligating brackets $(\mathrm{p}<0.01)$. Under angulation, brackets with a slide mechanism produced higher friction than the same brackets under zero angulation $(\mathrm{p}<0.01)$. Nevertheless, the slide system under angulation produced smaller friction values than conventional brackets tied with elastomeric ligatures in $0^{\circ}$ tests.

Keywords: Orthodontic brackets. Friction. Stainless steel. Ligation.

${ }^{1}$ Specialist in Orthodontics, Rio de Janeiro State University.

${ }^{2}$ Associate Professor, Laboratory of Biomaterials, Military Institute of Engineering, Brazil. PhD in Sciences, Military Institute of Engineering, Brazil.

${ }^{3}$ Collaborator of Department of Orthodontics, Rio de Janeiro State University. PhD in Orthodontics, Rio de Janeiro State University. PhD Student in Sciences, Military Institute of Engineering, Brazil.

${ }^{4}$ Adjunct Professor and Coordinator, MSc Degree Program in Orthodontics, Rio de Janeiro State University.

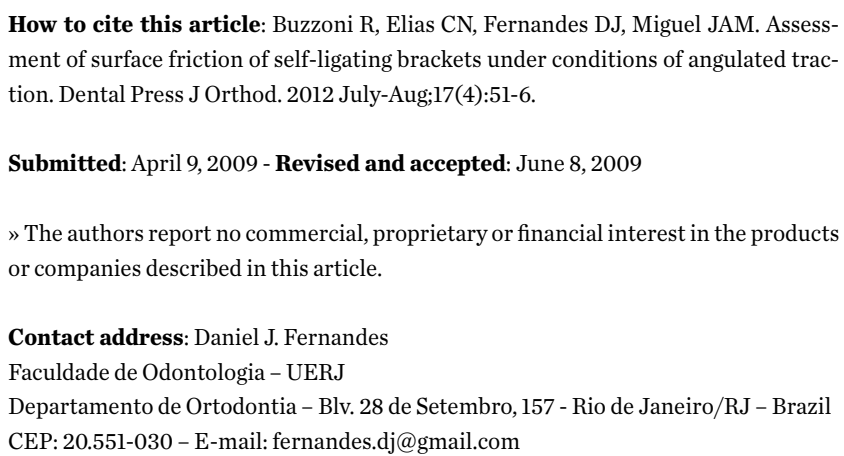

How to cite this article: Buzzoni R, Elias CN, Fernandes DJ, Miguel JAM. Assessment of surface friction of self-ligating brackets under conditions of angulated traction. Dental Press J Orthod. 2012 July-Aug;17(4):51-6.

Submitted: April 9, 2009 - Revised and accepted: June 8, 2009

» The authors report no commercial, proprietary or financial interest in the products or companies described in this article.

Contact address: Daniel J. Fernandes Faculdade de Odontologia - UERJ

Departamento de Ortodontia - Blv. 28 de Setembro, 157 - Rio de Janeiro/RJ - Brazil CEP: 20.551-030 - E-mail: fernandes.dj@gmail.com 


\section{Avaliação da fricção superficial apresentada por braquetes autoligáveis em condições de tracionamento sob angulação}

Roberta Buzzoni', Carlos N. Elias², Daniel J. Fernandes ${ }^{3}$, José Augusto M. Miguel ${ }^{4}$

Objetivo: avaliar a fricção apresentada por braquetes autoligáveis de aço inoxidável com sistema passivo de tampa deslizante sob angulação de 0 grau e 2,5 graus, e comparar o comportamento desse grupo sob angulação nula com o de um grupo de braquetes autoligáveis com sistema ativo de tampa resiliente.

Métodos: foram utilizados 25 braquetes de caninos superiores, divididos em 5 grupos - braquetes autoligáveis passivos Damon SL II sob angulação de 0 grau e de 2,5 graus; braquetes convencionais Gemini amarrados com ligaduras elásticas sob as mesmas angulações; e um grupo formado pelo sistema ativo Time 2, sob angulação nula. A hipótese a ser testada é se artefatos autoligáveis com sistema de tampa passiva são mais efetivos no controle da fricção do que dispositivos contendo coberturas ativas. $O$ tracionamento foi realizado segundo emprego de 25 segmentos de fio de aço inoxidável 0,020” na máquina de ensaios EMIC DL 10000 com célula de carga de 2,0kg. Cada conjunto braquete/fio foi responsável pela geração de quatro corpos de prova, totalizando-se 100 leituras. As comparações entre médias dos valores foram realizadas através da Análise de Variância (one-way ANOVA) com correções pelo coeficiente de Bonferroni.

Resultados e Conclusão: as médias de fricção encontradas confirmaram a hipótese em teste, de que o sistema de braquetes Damon SL II é mais eficiente no controle do atrito do que o sistema de tampa ativa sob angulação de 0 grau $(p<0,01)$. Quando submetidos a angulações de 2,5 graus, a friç̧ão aumentou significativamente $(p<0,01)$, porém mantendo-se ainda muito inferior aos patamares evidenciados no grupo de braquetes convencionais amarrados com ligaduras elásticas.

Palavras-chave: Braquetes. Fricção. Aço inoxidável.

${ }^{1}$ Especialista em Ortodontia pela UERJ.

${ }^{2}$ Professor Associado do Instituto Militar de Engenharia (Laboratório de Biomateriais). Doutor em Ciências pelo Instituto Militar de Engenharia (IME).

${ }^{3}$ Colaborador do Departamento de Ortodontia da UERJ. Doutor em Ortodontia pela UERJ. Aluno de Doutorado em Ciências pelo IME.

${ }^{4}$ Professor Adjunto da disciplina de Ortodontia da UERJ. Doutor em Odontologia pela UFRJ.

\begin{abstract}
Como citar este artigo: Buzzoni R, Elias CN, Fernandes DJ, Miguel JAM. Assessment of surface friction of self-ligating brackets under conditions of angulated traction. Dental Press J Orthod. 2012 July-Aug;17(4):51-6.

Enviado em: 9 de abril de 2009 - Revisado e aceito: 8 de junho de 2009

» Os autores declaram não ter interesses associativos, comerciais, de propriedade ou financeiros que representem conflito de interesse nos produtos e companhias descritos nesse artigo.
\end{abstract}

Endereço para correspondência: Daniel J. Fernandes Faculdade de Odontologia - UERJ

Departamento de Ortodontia - Blv. 28 de Setembro, 157 - Rio de Janeiro/RJ CEP: 20.551-030 - E-mail: fernandes.dj@gmail.com 


\section{INTRODUCTION}

Maintaining low levels of friction constitutes a concurrent objective when producing orthodontic movement. Frictional forces are dependent on variables such as alloy type, size, shape of the orthodontic brackets ${ }^{6,16,20}$ and shape of archwire ${ }^{2,6,16,20}$ in addition to characteristics inherent in the interaction between appliances, such as ligation ${ }^{2,21}$ and the angulation established between these appliances. ${ }^{3,7-9}$

Self-ligating (SL) brackets are designed to engage the orthodontic archwire in the bracket slot in a unique manner ${ }^{10,19,21}$ (Fig 1). Such engagement can be classified as active or passive. ${ }^{16,58}$ SL brackets are considered active ${ }^{2}$ when they feature a resilient cover capable of exerting constant pressure on the orthodontic archwires. ${ }^{6,10,21}$ Contact between archwire and the resilient cover is established only when the archwire has a cross section greater than 0.017in. Smaller archwires remain fully retained inside the bracket slot without receiving any pressure. In these situations, the self-ligation method can be classified as passive. ${ }^{10,19}$ Berger et al described the action produced by the system on tooth alignment and leveling in terms of greater control of rotations and torques. ${ }^{2}$ A passive system can also be comprised with a cover mechanism which is capable of holding the archwire passively, regardless of wire cross section. In this model, the bracket slot resembles an orthodontic tube when the cover mechanism is closed. ${ }^{10,21}$ Some authors ${ }^{17,20}$ believe that this passive model is more efficient in controlling friction than the active mechanism, be the appliance passive or active. The hypothesis to be tested is whether or not self-ligating appliances with a slide mechanism are more effective in controlling frictional forces than appliances with resilient cover mechanisms.

The aim of this study was to assess the frictional forces produced by stainless steel SL brackets with a passive mechanism under zero and $2.5^{\circ}$ of angulation and to compare the behavior of this group, without angulation, to active self-ligating brackets.

\section{MATERIAL AND METHODS}

This study used 25 canine brackets divided into five distinct groups (Tab 1). The groups comprised Damon SL II, a passive self-ligating system(Ormco, CA, USA) under $0^{\circ}$ and $2.5^{\circ}$ angulation, Gemini conventional brackets (3M/Unitek, CA, USA) tied conventionally with gray elastomeric ligatures (TP Orthodontics, IN, USA) under the same angulations,
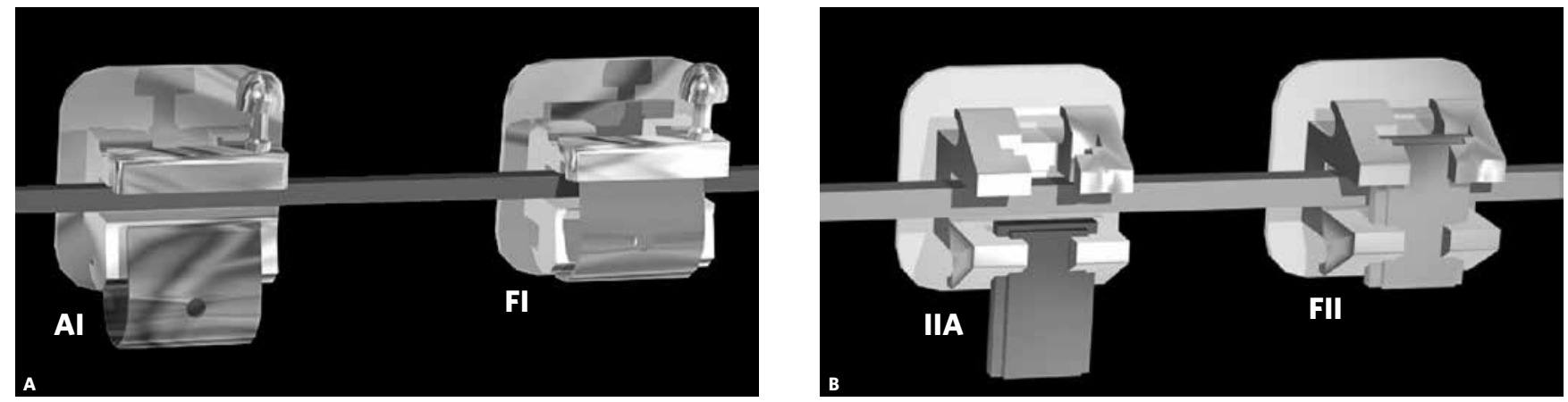

Figure 1 - A) Front view of self-ligating brackets fitted with a self-ligation system consisting of a resilient front cover in open (AI) and closed (FI) position, similar to Time 2 brackets. B) Front view (II) of self-ligating brackets fitted with an anterior slide mechanism in an open (IIA) and closed (FII) position, similar to what is found in Damon SL II brackets.

Table 1 - Description of groups, ligation system, quantities, pre-angulations and pre-torques in the prescriptions, and angulations used in the bracket traction tests.

\begin{tabular}{ccccccc} 
Groups & Brackets & Ligation system & Number of brackets & Pre-angulations & Pre-torques & Test angulations \\
\hline 1 & Damon SL II & Passive & 5 & $+6^{\circ}$ & $0^{\circ}$ & $0^{\circ}$ \\
2 & Time 2 & Active & 5 & $+9^{\circ}$ & $-2^{\circ}$ & $0^{\circ}$ \\
3 & Damon SL II & Passive & 5 & $+6^{\circ}$ & $0^{\circ}$ & $2,5^{\circ}$ \\
4 & Gemini & Elastomeric ligature & 5 & $+8^{\circ}$ & $0^{\circ}$ & $0^{\circ}$ \\
5 & Gemini & Elastomeric ligature & 5 & $+8^{\circ}$ & $0^{\circ}$ & $2,5^{\circ}$ \\
\hline
\end{tabular}


and a group consisting of Time 2 active self-ligation system(American Orthodontics, WI, USA) under zero angulation (Fig 2). Traction tests used twentyfive $8 \mathrm{~cm}$ segments of round 0.020 -in stainless steel orthodontic wire (TP Orthodontics, IN, USA). Each bracket/wire set generated four specimens. Analysis of the friction produced by pulling the steel wires inside the bracket slots was assessed based on four consecutive readings. There were twenty specimens in each group, totaling 120 different readings.

The friction of the bracket/wire was measured in an Emic DL 10000 testing machine (Emic, Brazil) with a load cell of two kilograms (kg). In order to

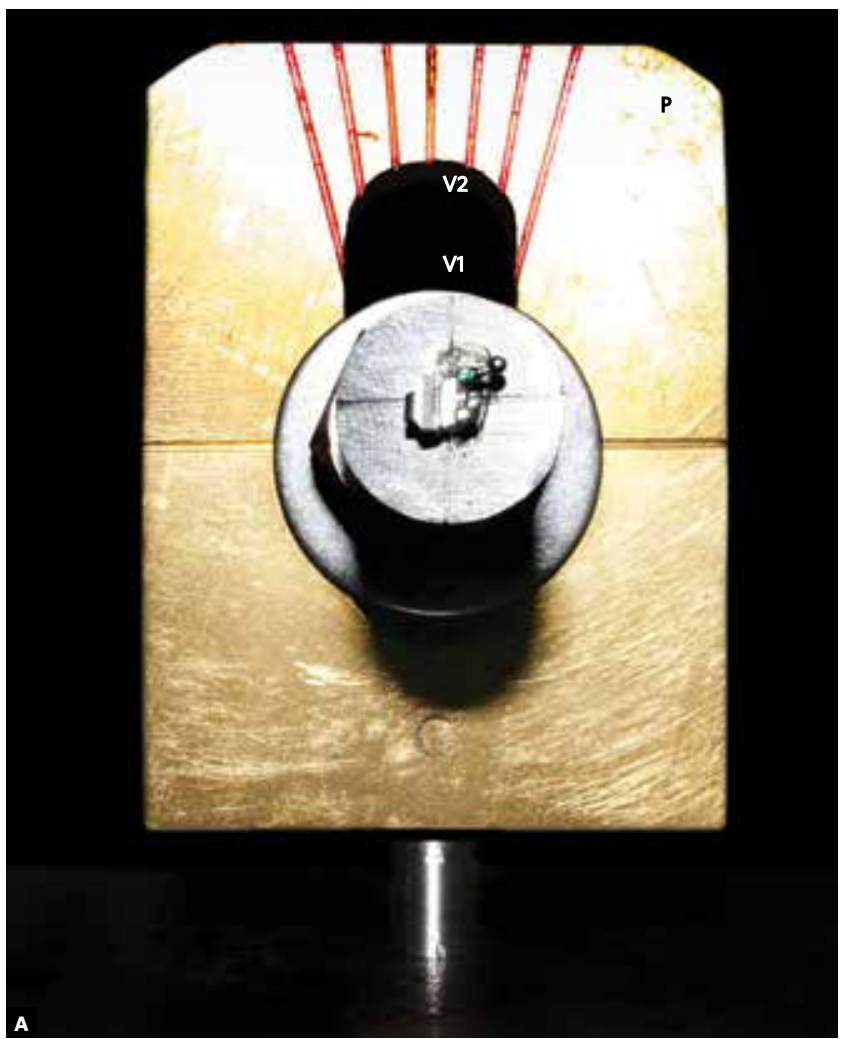

offset the different angulations built into the preadjusted brackets, metal cylinders were specially developed with compensatory angulations to ensure that all archwires were positioned parallel to the bracket slots (Fig 2). These stainless steel cylinders were connected to the testing machine while the appliances were bonded with the aid of Super Bonder instant adhesive (Loccite, Brazil). The bracket bases were filled with Transbond XT light-cure adhesive (3M/ Unitek, CA, USA) in order to standardize the bonding area (Fig 3). In the groups where angulations were included, the cylinder was rotated $2.5^{\circ}$ in the base part connected to the testing machine (Fig 4).

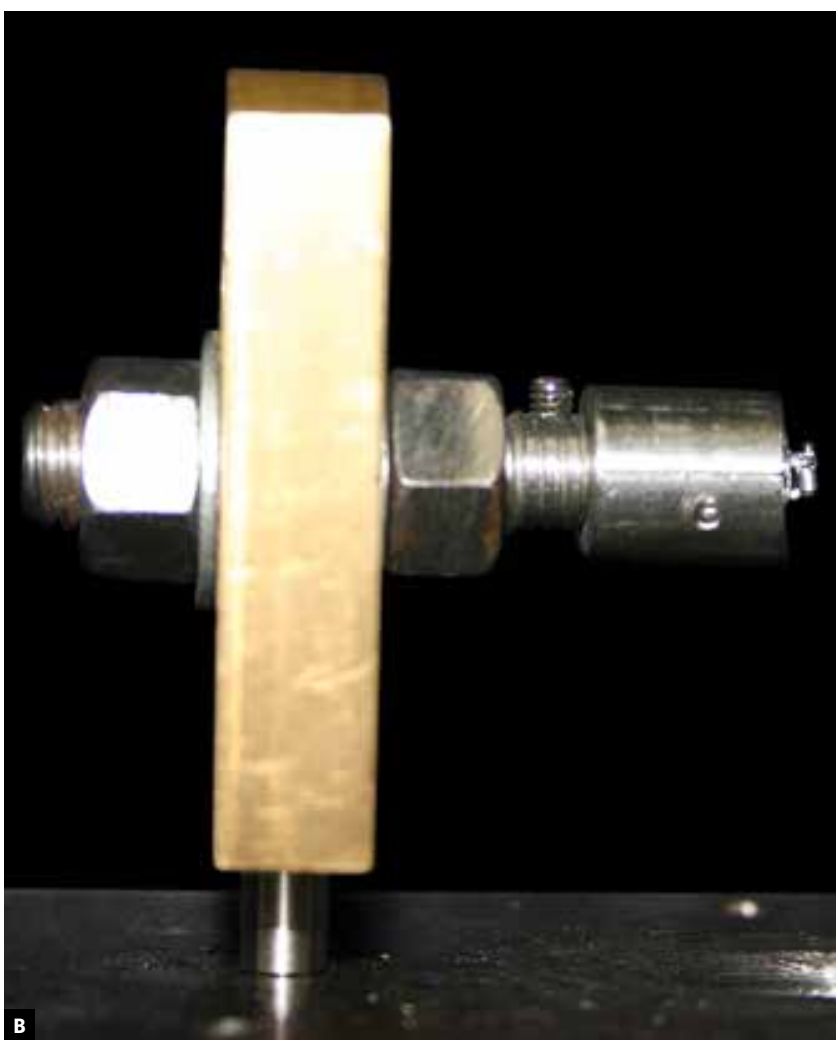

Figure 2 - A) Front view of a Time 2 bracket bonded to a metal cylinder with $-9^{\circ}$ offset angulation to ensure that the wires are pulled without tip or torque Total absence of angulation (tip) can be confirmed by aligning the existing vertical markings VI and VII with the metal cylinder and with a copper colored part (P) seen in the background. (II) Side view of the same appliance described above. Note the number printed on the cylinder denoting a $-9^{\circ}$ offset angulation (tip). B) Side view of the same appliance described above. Note the number printed on the cylinder denoting a $-9^{\circ}$ offset angulation (tip).

Table 2 - Self-ligating brackets, test angulations, surface friction means in gram-force ( $\mathrm{gF}$ ), standard deviations and number of specimens subjected to round 0.020 -in stainless steel wire traction.

\begin{tabular}{ccccc}
\hline Self-ligating brackets & Test angulations & Means (gF) & Standard deviations & Specimens (n) \\
\hline Damon SL II & $0^{\circ}$ & $1.171^{\mathrm{a}}$ & 0.6461 & 20 \\
Time 2 & $0^{\circ}$ & $3.219^{\mathrm{b}}$ & 0.5239 & 20 \\
Damon SL II & $2.5^{\circ}$ & $18.53^{\mathrm{c}}$ & 3.507 & 20 \\
\hline
\end{tabular}

Conventional Gemini brackets under $0^{\circ}$ angulation: Mean $(\mathrm{gF})=114.4$.

Conventional Gemini brackets under $2.5^{\circ}$ angulation: Mean $(\mathrm{gF})=183.5$.

ANOVA: Different letters imply different means by the Bonferroni multiple comparisons test $(p<0.01)$. 
The archwires used in the Gemini groups were tied with elastomeric ligatures, which were changed at every test (Fig 4).

The orthodontic wires were pulled at a speed of $5 \mathrm{~mm} / \mathrm{min}$ covering a distance of $3.5 \mathrm{~mm}$ (Fig 2). Maximum force ( $\mathrm{gF}$ ) values were recorded using Tesc software, version 3.04 (Emic, Brazil).

Mean values were compared by analysis of variance (one way ANOVA) and corrected with the Bonferroni coefficient. All analyzes were performed with Graphpad Prism software version 4.0 (Graphpad Software, CA, USA).

\section{RESULTS}

Distribution of force ( $\mathrm{gF}$ ) values are depicted in a box-plot chart. (Fig 5). Distribution was not normal according to the Shapiro-Wilk test $(\mathrm{p}<0.05)$.

The data is summarized (Table 2 ) by means and standard deviations. Friction was evaluated and compared in grams-force $(\mathrm{gF})$ under traction with a round 0.020 -in stainless steel wire. The findings suggest lower friction means for the self-ligating groups compared with conventional brackets tied with elastomeric ligatures. A more effective frictional control was achieved in the passive selfligating system when these brackets were tested with no angulation. Under a $2.5^{\circ}$ angulation, the frictional force increased in the self-ligating and conventional groups $(\mathrm{p}<0.01)$.

ANOVA revealed associations between frictional forces and self-ligating systems. The $\mathrm{p}$ value $(\mathrm{p}<$ 0.01) found using the Bonferroni multiple comparisons test indicated differences between groups (Table 2).

\section{DISCUSSION}

Surface friction generated by sliding an orthodontic archwire inside a bracket slot opposes the tendency of tooth movement intended when delivering orthodontic forces. A greater friction effect can be observed in sliding mechanics widely used in first premolar extraction cases, where distalization of canine teeth is recommended. With the purpose of ensuring a correct simulation of clinical conditions, canine brackets were employed. The same brackets were also used in studies conducted by Berger et $\mathrm{al}^{3}$ and Braun et al. ${ }^{4}$

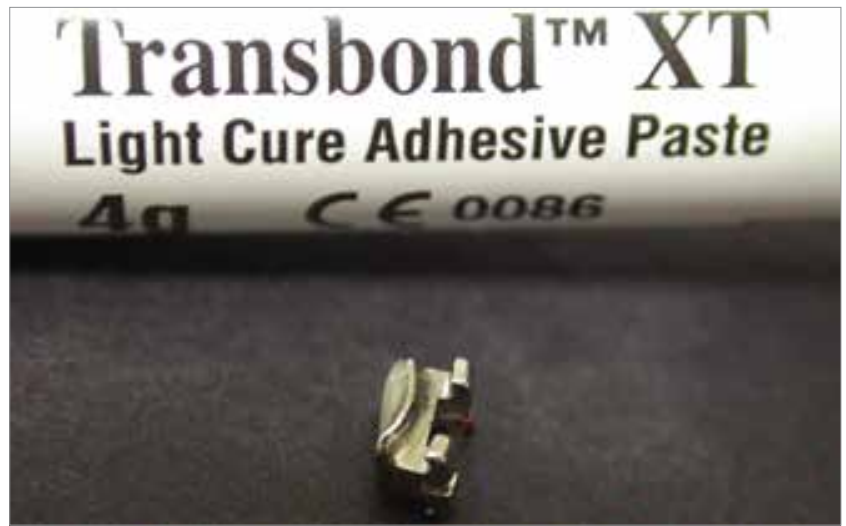

Figure 3 - Gemini bracket bases filled with resin for subsequent bonding to the surface of metal cylinders. Note how the bases were levelled (filled) with Transbond XT light cure adhesive.

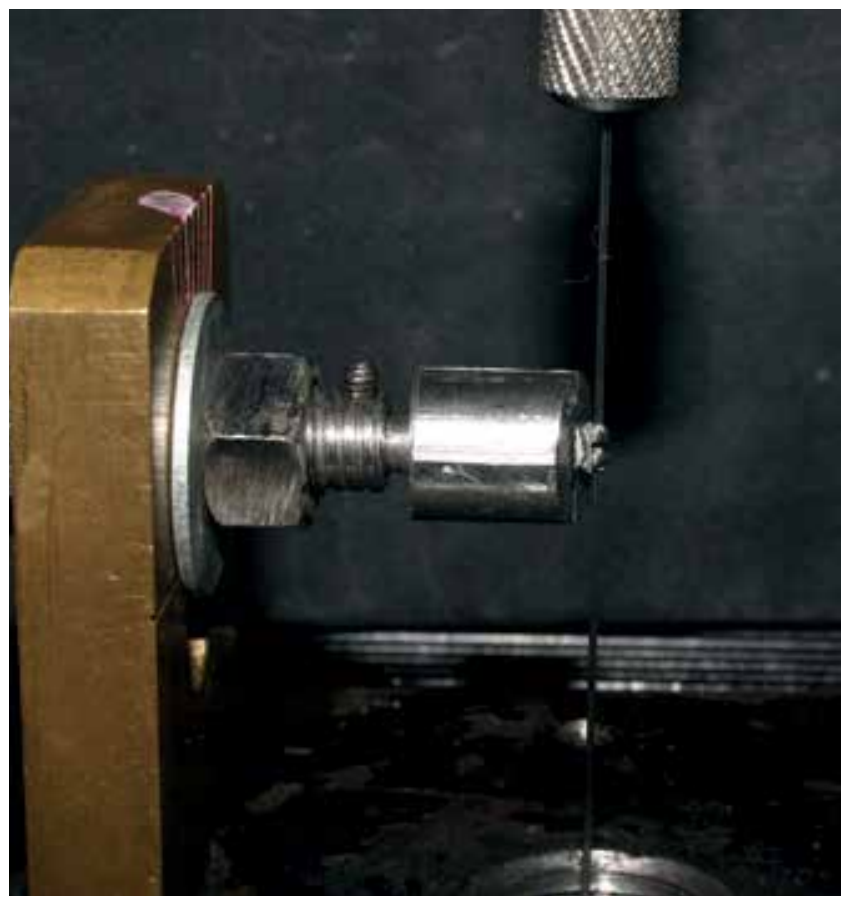

Figure 4 - Stainless steel wires being pulled at an angle of $2.5^{\circ}$ while engaged in the slots of Gemini brackets with the aid of gray elastomeric ligatures.

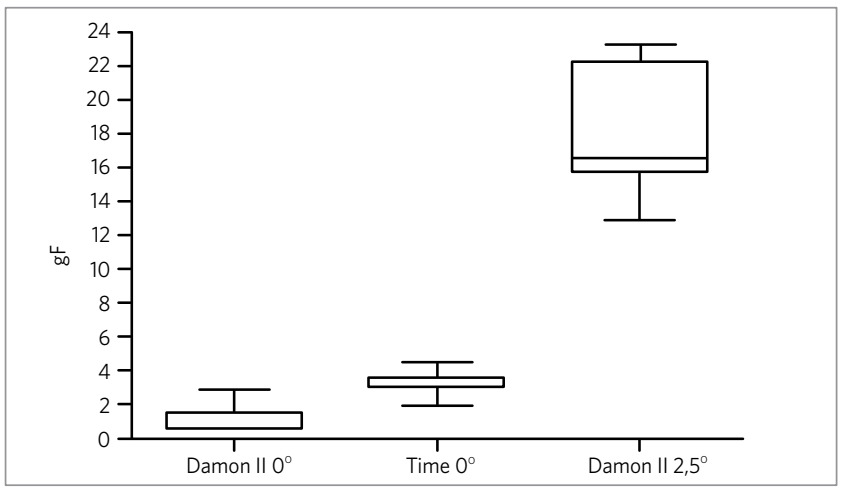

Figure 5 - Distribution of friction values in gram-force (gF) by self-ligating brackets at zero and $2.5^{\circ}$ angulation. 
Five brackets were tested in each group, with readings being performed at four different points, consecutively to pulling 0.020 -in round wires, totaling 20 specimens. This method was applied in order to simulate clinical conditions of sliding mechanics, repeatedly over a distance determined by the treatment goals. The results showed reduced standard deviations, which would render redundant repetitions with the same appliances. Voudoris et $\mathrm{al}^{21}$ used only eight brackets in each group, totaling twentyfour specimens for each bracket type. ${ }^{21}$ Although some authors argue that the surface of brackets and/or wires ${ }^{11-13}$ are susceptible to wear, such wear is perhaps more significant in appliances featuring a higher coefficient of friction such as polycarbonate or polycrystalline matrix.

Bracket design and size - as well as bracket angulations and torques ${ }^{8,14,15}$ - have a direct relation on friction. ${ }^{7,8,9,14,15,20}$ Each manufacturer designs a unique individual self-ligation method. In order to standardize the different prescriptions metal cylinders were fabricated with surfaces that were individually beveled to ensure bondings with no angulations or torques. Authors have used different methods to standardize pre-existing bracket angulations and torques. ${ }^{4,5,21}$ Studies conducted by Sims et $\mathrm{al}^{17}$ also employed metal parts to ensure a parallel positioning of bracket slots relative to orthodontic archwires when bonding the brackets.

Upon selection of canine brackets for use in this experiment it was found that the bases of these brackets were too concave, which might raise a bonding issue. It was necessary to fill the bases with light-cure resin, thereby ensuring each base was levelled to facilitate bonding. Voudoris et al used in their study the same resin filling method and found no variation in friction values as a result of this approach. ${ }^{21}$

Given that tooth sliding is made up of a series of numerous small inclination movements, ${ }^{6}$ selfligating brackets featuring an anterior passive sliding mechanism were subjected to an angulation of $2.5^{\circ}$ upon being pulled. Although studies conducted by Read-Ward et $\mathrm{al}^{16}$ employed up to $10^{\circ}$ angulations, angulations above $2.5^{\circ}$ produced - in a previous pilot study - force magnitudes which are not viable in clinical practice. Active resilient self-ligating brackets were not angulated due to the inaccuracy likely to be generated during friction. A lack of standardization would occur in the interaction between the flexible bracket cover and the orthodontic wire being tipped, leading to changes in friction at each test. Some authors argue that friction is affected by the features of the surfaces being pulled. ${ }^{4,6}$

One important factor influencing friction magnitude is the ligation method used to engage the orthodontic wire in the bracket slot., ${ }^{718}$ Currently, the standard ligation system for conventional brackets involves the use of elastomeric ligatures. Metal ligatures produce variable forces according to the technique used by each profissional. ${ }^{11,21}$ However, it has been reported that elastomeric ligatures lose some of their elastic capacity when held stretched, which alters any surface friction being generated. ${ }^{17}$ In order to limit the number of variables, elastomeric ligatures were changed at every mechanical test.

The results of this study suggest that self-ligating brackets exhibited lower friction values than conventional brackets tied with elastomeric ligatures, as reported in the literature. ${ }^{2,3,4,14,18,21}$ The aim of this study was to assess the behavior of brackets with different self-ligation systems tipped at many different angulations. The mean values found for the conventional Gemini system served only as reference and were therefore not treated statistically. In comparing the self-ligating groups statistically when the brackets were pulled with no angulation, the group with brackets equipped with an anterior passive slide mechanism showed greater friction control compared to the active resilient system. This finding is supported by other authors ${ }^{19}$ and could be related to a better filling of the bracket slot observed in resilient system, as well as to the pressure exerted by the active cover on the orthodontic wire.

In pulling conventional brackets and self-ligating brackets with a slide mechanism at an angle of $2.5^{\circ}$ there was a significant increase in friction compared to the same appliances at $0^{\circ}$ angulation. This behavior suggests that there is a direct relationship between angulated traction and surface friction, a relationship that has been observed in other investigations. ${ }^{1,14,18}$ 
This study conducted laboratory tests simulating clinical practice as closely as possible. However, tests are limited and often fail to faithfully reproduce the friction generated during clinical procedures. Surface friction values may be different from the forces delivered by intraoral orthodontic systems. Moreover, passive and active self-ligating appliances may differ in terms of clinical significance. The values found in the study should be used only as a yardstick to compare the effects of different types of self-ligating brackets and not to accurately quantify in vivo surface friction.

\section{CONCLUSIONS}

After assessing passive self-ligating brackets, it was observed that when used at $2.5^{\circ}$ of angulation they were less effective in controlling friction than when used under no angulation.

When comparing the self-ligating systems at zero angulation, the hypothesis being tested was confirmed since passive self-ligating brackets proved to be more effective in controlling friction compared to the active system.

\section{REFERENCES}

1. Bednar JR, Gruendeman GW, Sandrik JL. A comparative study of frictional forces between orthodontic brackets and arch wires. Am J Orthod Dentofacial Orthop. 1991 Dec;100(6):513-22.

2. Berger JL. The SPEED appliance: a 14-year update on this unique self-ligated orthodontic mechanism Am J Orthod Dentofacial Orthop. 1994 Mar;105(3):217-23.

3. Berger JL. The influence of the SPEED bracket's self-ligating design on force levels in tooth movement: A comparative in vitro study. Am J Orthod Dentofacial Orthop. 1990 Mar;97(3):219-28.

4. Braun S, Bluestein M, Moore BK, Benson G. Friction in perspective. Am J Orthod Dentofacial Orthop. 1999 Jun;115(6):619-27.

5. Clocheret K, Willems G, Carels C, Celis JP. Dynamic frictional behavior of orthodontic archwires and brackets. Eur J Orthod. 2004 Apr;26(2):163-70

6. Closs LQ, Mundostock KS, Gandini Junior LG, Raveli DB. Os diferentes sistemas de bráquetes Self-ligating: revisão de Literatura. Rev Clín Ortod Dental Press. 2005 Abr-Maio;4(2):60-6

7. Dickson JA, Jones SP, Davies EH. A comparison of the frictional characteristics of five initial alignment wires and stainless steel brackets at three brackets to wire angulation - an in vitro study. Br J Orthod. 1994 Feb;21(1):15-22.

8. Drescher D, Bourauel C, Schumacher HA. Frictional forces between bracket and archwire. Am J Orthod Dentofacial Orthop. 1989 Nov;96(5):397-404

9. Frank CA, Nikolai RJ. A comparative study of frictional resistances between orthodontic bracket and arch wire Am J Orthod. 1980 Dec;78(6):593-609.

10. Harradine NW. Self-ligating brackets: Where are we now? J Orthod. 2003 Sep;30(3):262-73.

11. Kapur R, Sinha PK, Nanda RS. Comparison of frictional resistance in titanium an stainless steel brackets. Am J Orthod Dentofacial Orthop. 1999 Sep;116(3):271-4

12. Keith $\mathrm{O}$, Jones SP, Davies $\mathrm{EH}$. The influence of bracket material ligation force and wear on frictional resistance of orthodontic brackets. Br J Orthod. 1993 May;20(2):109-15.
13. Loftus BP, Artun J, Nicholls JI, Alonzo TA, Stoner JA. Evaluation of friction during sliding tooth movement in various bracket-arch wire combinations. Am J Orthod Dentofacial Orthop. 1999 Sep;116(3):336-45.

14. Ogata RH, Nanda RS, Duncanson MG Jr, Sinha PK, Currier GF. Frictional resistances in stainless steel bracket-wire combinations with effects of vertical deflections. Am J Orthod Dentofacial Orthop. 1996 May;109(5):535-42.

15. Pizzoni L, Ravnholt G, Melsen B. Frictional forces related to self-ligating brackets. Eur J Orthod. 1998 Jun;20(3):283-91.

16. Read-Ward GE, Jones SP, Davies EH. A comparison of self-ligating and conventional orthodontic bracket systems. Br J Orthod. 1997 Nov;24(4):309-17.

17. Sims AP, Waters NE, Birnie DJ. A comparison of forces required to produce tooth movement ex vivo through three types of pre-adjusted brackets when subjected to determined tip or torque values. Br J Orthod. 1994 Nov;21(4):367-73.

18. Taylor NG, Ison K. Frictional resistance between orthodontic brackets and archwires in the buccal segments. Angle Orthod. 1996;66(3):215-22.

19. Voudouris JC. Interactive edgewise mechanism: form and functional comparison with conventional edgewise brackets. Am J Orthod Dentofacial Orthop. 1997 Feb;111(2):119-40.

20. Thomas S, Sherriff M, Birnie D. A comparative in vitro study characteristics of two types of self-ligating brackets and two types of pre-adjusted edgewise brackets tied with elastomeric ligatures. Eur J Orthod. 1998 Oct;20(5):589-96.

21. Thorstenson GA, Kusy RP. Effects of ligation type and method on the resistance to sliding of novel orthodontic brackets with second-order angulation in the dry and wet states. Angle Orthod. 2003 Aug;73(4):418-30. 